IDEAH • Vol. 1, Iss. 1 (DHSI 2017 \& 2018)

\title{
Punching Holes in the International Busa Machine Narrative
}

\section{Arun Jacob}

Published on: May 31, 2020

DOI: $10.21428 / f 1 f 23564 . d 7 d 097 c 2$

License: Creative Commons Attribution 4.0 International License (CC-BY 4.0). 
The fabled origin story of humanities computing takes place in 1946 when Jesuit Priest Father Roberto Busa and Thomas J. Watson Sr. the CEO of International Business Machines (IBM) meet, exchange pleasantries, and lay the groundwork for producing an index of the complete writings of Saint Thomas Aquinas (Winter 4). Busa and Watson's meeting marks the genesis of the field since the theologian was able to acquire the material, technical, and financial support from the technocrat to engage in his scholarly endeavour, developing a linguistic corpus using computing technologies. This illustrious digitization project of sorting and indexing 11 million words of medieval Latin in the works of St. Thomas Aquinas produced a touchstone for humanities computing, the Index Thomisticus (Hockey 4). Busa, along with IBM technicians, developed machine-readable concordances and in the process, built a bibliography that was searchable through a telephonic coupler. Busa's pioneering work, "Exploring the Concept of Presence According to Thomas Aquinas" (83), was accomplished by repurposing business machines developed primarily for record-keeping to generate automated concordances that have been widely celebrated as the genesis of the field of humanities computing, later christened digital humanities.

In this paper, I will be studying how the cultural memory of Fr. Roberto Busa's humanities computing project has been shaped, formed, and contoured in contemporary digital humanities scholarly discourse. By broaching the topic of the provenance of computational approaches to humanities and by revisiting the origins of the traditions and practices of computer-assisted text analysis, it becomes evident how, as Torgovnick claims, "[a]s part of a social bargain, individuals and groups agree to look away from unsettling histories, which then form the latent contents of cultural memory - not erased from memory (Halbwachs's concept) so much as a consequential, even active absence: the hole, to put it colloquially, that completes the donut, necessary for the donut's very shape" (3). By studying the narrative arcs that lead up to and/or are left out from the genealogical history of the field of digital humanities, I hope to offer a counter-hegemonic cultural memory. My narrative critique stems from locating the genesis of the field of humanities computing at the feet of Busa and revering him as the great man of digital humanities. Taking my cue from Ramon Reichert's assertion that neither Busa's research question nor his methodological procedure was novel, I trace the lineage of the field of study by teasing out the more extended history of the computing infrastructure that was at Busa's disposal and critically perusing the media archeology of punch-card technologies through curated corporate accounts and their relation to cultural memories (2).

The conventional historiography that pivots around Busa's founding father storyline and his savoirfaire silences the socio-econo-political lived realities of space/time where and when work on humanities computing took place. Haunting the timeline when Busa was working on the Index Thomisticus includes details like how, during World War II, Busa served as a military chaplain in the auxiliary corps of the Italian Army from 1940-1943 (Bonfanti 60). As a graduate student in the 
Pontifical Gregorian University in Rome, working on his dissertation on Thomistic theology, Busa was seemingly unaffected being "surrounded by bombings, Germans, partisans, poor food and disasters of all sorts" (Jones 35). I found it quite disconcerting that a man of the cloth was so socially disaffected by the catastrophes happening around him. Zygmunt Bauman theorizes that in a bureaucracy, moral concerns are not matters that are discussed; instead, the object of bureaucratic labour is to produce flawless work (98). The excellence with which the task is performed is the only metric of concern for the bureaucrat; there is no room for ethical concerns in this operational paradigm. I would opine that Busa's research project is symptomatic of the schemata that Bauman describes in his apparent lack of social care. As much as the field of digital humanities owes to its founding father, it is worth clarifying that Busa's pioneering research in humanities computing resides at the intersection of the workings of three gargantuan bureaucracies: academia, the Catholic Church and the IBM corporation. As a Jesuit priest, Busa reported to the ecclesiastical office of Pope Pius XII. In his industry-university collaborative endeavour, he liaised with Thomas J. Watson Sr., the CEO of IBM. Both Pope Pius XII and Thomas Watson leave behind very troubling legacies and unsettling histories vis-à-vis their respective relationships with the Third Reich (Black 10).

The sanitized digital humanities origin story fails to acknowledge the provenance of the punch card technology and the purpose for which the technologies were socially constructed. Before there was humanities computing, however, there was a computational social science. The IBM punch-card technology used by Busa has its history of being handled by the Nazi regime wiped clean from digital humanities historiographies. I believe that if we are to acknowledge punch-card technology as an essential part of the genesis of digital humanities, we must be cognizant of the logic of hierarchy and inequality that is baked into the history of the punch cards. IBM punch cards were the data processing technology used by the Third Reich to instrumentalize race science, operationalize surveillance, and in the process automation of human extermination (Black 12). IBM president Thomas J. Watson, Order of the German Eagle recipient and president of the International Chamber of Commerce in 1937, was personally involved in IBM's project management of Hitler's extermination campaign (Black 147; Maney 208). The New-Deal policies that curtailed American corporate operations in Europe did not affect IBM because of the personal relationships that Watson had cultivated with US Presidents Roosevelt, Truman, and Eisenhower (Maney 172; Stebenne 49). IBM subsidiaries were fully functional at the time of World War II and operating business ventures through units in Germany and Switzerland (Pauwels 236). IBM's German subsidiary Dehomag (Deutsche Hollerith-Maschinen Gesellschaft mbH - German Hollerith Machines LLC) redesigned the Hollerith punch cards initially used in the Hollerith Machine to electronically tabulate census returns to track people, and perform the information and tabulation tasks required to operationalize the holocaust by the Third Reich (Black 265). Using Dehomag's punch-card technology, the Third Reich was able to operationalize the "final solution" precisely and accurately on account of the superior information processing and 
database management systems that IBM's cybernetic infrastructure provided. The rationality of the bureaucrats who were looking for the most efficient and effective method to exterminate the Jews during World War II explains how technology and ideology were sutured together under Nazism. Dehomag's technical expertise yokes the Nazi system of totalitarian control and coordination to the vulgar extreme of IBM's capitalist enterprise.

My research endeavour is in locating the Torgovnickian absent-presence in the origin story of digital humanities. Engaging in a hauntological reading of the great man narrative, I hope to unveil the spectral revenants that lurk underneath the surface by carefully teasing out the provenance of the punch card technology, the particularities of the political-economy within which the technology emerged, and historically contextualizing the social and cultural affordances that enabled the technology to be adopted. By mobilizing Paul Ricœur's "hermeneutics of suspicion" I will be peering into the nooks and crannies of the cultural record for what has been left out and/or unsaid from the canons of digital humanities to argue that shed light on some of the socio-cultural contexts that shaped Busa's work further reveals how this domain of research emerged (30). By recalling, recollecting, and remembering the cultural legacies of the genesis of humanities computing, suturing the problematic histories of Busa's project to the contemporary technoscape, and unsettling the original disciplinary narrative, I am of the opinion that it is worth investing some scholarly energies into cultivating an "ethics of memory" to critically peruse the culture, climate, and values of the space/time from where the Index Thomisticus originated and inculcating in digital humanists a "duty to remember" a more nuanced origin story with blemishes, flaws, follies, and all (89).

The most fertile ground from where to begin analyzing the relation of history and memory in Busa's narrative was by critically reviewing a gap in the literature that stemmed from his own admission of ignorance when he wrote,

"Although some say that I am the pioneer of the computers in the humanities, such a title needs a good deal of nuancing... [O]n the stacks of the IBM library in New York City I had spotted a book (whose title I have forgotten), which was printed sometime between 1920 and 1940: in it someone mentioned that it was possible to make lists of names by means of punched cards" (Busa 84).

The founding father of the discipline of digital humanities openly confessing that he was aware that someone else at IBM had created machine-generated concordances several years before his own attempts is at once both intriguing and infuriating to me. What was the object of including such a vague and inchoate statement in this piece? While reading this passage, I began asking myself, is it possible this man was feigning ignorance of the origins of machine-generated concordances? Was there malicious intent on Busa's part in excluding the details of the progenitor of the IBM punch card technology? Busa, who has been described on several occasions as a meticulous and methodical researcher to have written such a sloppy entry, signalled to me that something was awry (Passarotti 17; 
Winter 16; Rockwell; Passarotti and Nyhan 8). For a scholar revered as an academic giant in the fields of philological, linguistic, and literary computing to leave out crucial details such as the title of the book he read, the author of the book mentioned above, the publication year, etc. did seem very peculiar and made it seem that something was amiss. This intuition prompted me to pursue the spectral voices haunting Busa's academic legacy and destabilizing the narrative built around the Index Thomisticus. I was transfixed by the question: what could have been Busa's rationale for obfuscating the text mentioned above and/or obliterating the cultural record in the process?

I gathered it was essential to acquaint myself with the punch card technology that Busa was working with, namely the IBM 858 Cardatype accounting machines, a series of storage-and-retrieval devices. Busa mentions the 858 Cardatype by name in the text as the technology that he had access to in order to work on his project. But, upon cross-checking with the IBM Archives, I noticed that the IBM 858 Cardatype was only developed in 1955 (Busa 84). Nico Sprokel writes that Busa was working on his doctorate in 1942, writing index cards by hand to produce a lexicographic and linguistic corpus of the Index Thomisticus (739). Since Busa's project began several years before this particular make and model of the IBM punch card machine was in service, I suspect Busa and his research team used earlier models of IBM machines over the years. In 1949, when Busa was commencing the project, Thomas Winter writes that Busa seemed acutely aware of the nitty-gritty details of the specific workings of the technology venture. Busa was very knowledgeable of the appurtenances that he would need to accomplish the empirical undertaking (Burton 1; Winter 6). I find it fascinating that a Jesuit priest had the project management skills and technological know-how to generate an engineering bill of materials that precisely met his project's technical needs. In Varia Specimina, Busa's first published report of the project, he describes his research methodology and the technical glitches that he encountered while repurposing the punched card tabulators to work on his humanities computing project with a glint of techno-optimism shining through in his writing (Winter 10). Busa's technical prowess and intuitive knowledge of knowing the glitches that the IBM punch-cards would produce does suggest to me that he may have had an intimate working knowledge of these tabulating machines. How, when, and where Busa may have come in contact with punch-cards to have gained this prior knowledge about the technicalities of punch-cards and its engineering paraphernalia merits further investigation.

The IBM 858 Cardatype accounting machine that Busa mentions in his writing is an example of a turnkey solution IBM offered to its business customers (Busa 85). IBM would provide to its business clients a turnkey computer system comprised of computer hardware, software, and applications developed and sold individually for the customer to meet the specific client's requirements. Perusing the 858 Cardatype Accounting Machine catalogue from August 20, 1957, I noticed that the machine was comprised of a control unit, a transmitting typewriter, a non-transmitting typewriter, an auxiliary keyboard, a cardatype card punch, a tape punch, and an arithmetic unit. IBM marketed the 858 
Cardatype Accounting Machine as a complete business solution and billed its customers for each of the components mentioned above separately. IBM did not sell its equipment to its customers; instead, they leased the hardware to customers and offered a service and maintenance contract for the upkeep of the computer. The tapes, ribbons, cards, etc. used in the 'Accounting Machine' were exclusive and proprietary to IBM.

I find Busa's discursive slippage problematic because, by using IBM’s sales and marketing term "Accounting Machine" in his writing, Busa glosses over the nuances of working with punch-card technologies. It is not a single machine this being deployed here instead it is a whole slew of devices, which are in turn then serviced by an army of IBM service personnel, organizational staff, administrative employees and key-punch operators. I'd argue that Busa's choice of words indicates how little he valued the working people that laboured on the operation of the machine. This becomes obvious in Busa's private disclosure to Edward Vanhoutte where it is described that

“[f]or his complete Index Thomisticus, Busa calculated that the stack of punch cards would have weighed 500 tonnes, occupying $108 \mathrm{~m}^{3}$ with a length of $90 \mathrm{~m}$, a depth of $1 \mathrm{~m}$, and a height of 1.20 m. By 1975, when the Index Thomisticus was completed and started to appear on 65,000 pages in 56 volumes (Busa, 1974-1980), some 10,631,973 tokens were processed" (127).

The quantitative data that Busa produced about the punch cards are duly noted in the cultural record and presented as historical fact. While there is no acknowledgement of the labour that went into creating these punch cards, each one of the punch cards that made up the 500 tonnes was each individually entered by female punch card operators. Punch card operators completed an apprenticeship in Busa's training institute in Milan, where they learned how to input, verify, and interpret the keypunch operations. Melissa Terras writes that Busa chose females over males, preferably those who did not know Latin in order to make sure they were conscientious and would not insert their interpretations into the text (Terras; Birnbaum, Bonde and Kestemont S2). There are photographs taken in Gallarate, Italy of female punch card operators working on Busa's project. But these photographs have not been appropriately catalogued. Therefore, it is not possible to discern when they were taken and/or who are the subjects in the photographic texts. These female punch-card operators are the midwives of knowledge creation, and they are left out of the origin story of digital humanities. I believe that is because Busa didn't see himself as one of the working people who laboured on the research initiative, rather that he preferred the corporate marketing discourse.

Busa's use of IBM's marketing jargon also suggests to me where his loyalties were, who he swore allegiances to, and who he associated himself with the public-private partnership. IBM offered this research project material and financial support for several decades. I thought it would be abundantly clear to Busa, as a religious scholar in the Pontifical Gregorian University, that publicly funded research ought to be for the public good, not private benefit. Moreover, as a priest, I expected Busa to 
value the link between Christianity, secular government, and society. Busa does not disclose in his writings the nature of the financial arrangement between IBM and the academic institution where his research project was housed. Geoffrey Rockwell, writing about the Index Thomisticus, mentions how our memory infrastructures are designed to preserve knowledge generated by projects without an adequate understanding of the workings of the project. He also notes that, from the Busa archives, it is evident that one of the side effects of having to obtain corporate sponsorship from IBM to conduct the project was that in return for bankrolling the project, IBM was looking for influence and publicity (Rockwell). I would maintain that Busa's project was a corporate social responsibility project and a public relations campaign for IBM.

Lars Heide points out that, "As early as 1926, IBM had decided not to base punched-card multiplications on an improved tabulator but to build a separate non-printing machine that could read figures from a punched card, perform the required arithmetic operations, and punch the outcome on the same or a successive card" (124). This exemplifies IBM's market-orientation to developing technological solutions. IBM did not pursue the more technically efficient and/or cost-effective engineering solution; instead, they invested their corporate energies into developing technologies that systemically prioritized the generation of profit over technical prowess. To this effect, it was James W. Bryce's design of having a separate punched-card multiplier that was patented in 1928 and implemented by IBM in the IBM Type 600 machine that was marketed in 1931 and upgraded to the Type 601 in 1931 to calculate multiplication and addition (124). IBM punch-card machines were not streamlined for technical efficiency because the mission of the business venture was to maximize the number of punch-cards sold. Therefore, any process that would undermine the sale and commerce of punchcards was antithetical to the corporate mission.

In 1928, Dehomag, IBM’s German subsidiary company, had brought Austrian engineer Gustav Tauschek's patent for a punched-card multiplier to the company's attention (Randell 129). Tauschek had filed for the patent in Germany in 1926, and he was awarded the patent in 1928. IBM saw the potential in Tauschek's patent and hired him on a contract from 1931 to 1935 as it bought up his numerous patents. IBM's strategy in hiring Tauschek was to make sure that no rival would capitalize on his intellectual property (Metropolis 599). IBM had made such a move in the past as well when the company bought out John Thomas Schaaff's electric typewriter and census tabulating machine patents, and John Royden Peirce's bookkeeping machine patents (Heide 108). In 1935, the United States Patent Office denied Gustav Tauschek's patent application and, in the process, denied him from gaining control of the rights to punched-card multiplication in the United States. Tauschek was let go from his contract at IBM around the same time as well. Meanwhile, IBM implemented several of Tauschek's patents in its product line in the years to come (Heide 124-5). 
Gustav Tauschek was a technical wizard whose other inventions include the first electromagnetic drum storage device and patenting the technology for optical character recognition in 1929 (W. Jones 1213). From 1926-1930, Tauschek worked for the military technology group Rheinmetall, (Rheinische Metallwaaren- und Maschinenfabrik AG - Rhine Metalware and Machine Factory Joint-Stock Company) where he developed the electro-mechanical punched-card accounting machine. Tauschek's punch-card machine prototype from 1928 was never mass-produced, and Rheinmetall sold off the company's punch-card technologies to Dehomag, IBM’s German subsidiary (Kistermann 41). Even though Tauschek's inventions never made it to market. I would imagine IBM acquired all the technical drawings, papers, monographs, and other writings that documented in detail how the punch-card technology could be operationalized. This leads me to believe that the mysterious book that Busa mentioned having come across in the book stacks of IBM's corporate library could very well have been one of the works of Gustav Tauschek. Since Tauschek's writings about the punch-card machine prototype were now in possession of IBM, I am of the opinion that it is not beyond a reasonable doubt that Busa may have been referring to one of Tauschek's texts that detailed a punch-cards use case scenario that could work for the machine-generated concordance project. By giving Tauschek credit for developing the tools and techniques that Busa would go on to use two to three decades later requires taking into account the social, cultural, political, and economic context from within which these technologies were researched and developed.

Rheinmetall, the company that Tauschek worked for, was an arms and ammunition manufacturing firm. Acknowledging Tauschek as a pioneer in the field is to draw a direct link between humanities computing and the Nazi military-industrial complex. Dehomag, IBM’s German subsidiary, was responsible for developing punch-card technologies for the Third Reich (Black 370). Although the punch-card technology was used in census-taking operations since the 1890 s for processing and tabulating data (Pugh 13), it was innovated upon, instrumentalized, and weaponized to execute the race science and surveillance agenda of the Third Reich. IBM's Dehomag was instrumental in the Nazi administrative efforts to record the vital statistics of every resident, and coordinate and conduct a comprehensive surveillance programme that was intent on arriving at the Final Solution (Luebke and Milton 27). Therefore, Busa was not merely repurposing business machines developed primarily for record-keeping; he was repurposing innovations in computing technologies developed by the militaryindustrial complex funded and used to operationalize the ideological agenda of the Nazi government.

I would argue that the allure of punch-cards and its technological innovations to both Busa and the Nazis, as administrators and bureaucrats, was its capacity to resolve the vexing problem of organizing a large ill-defined dataset. The punched-card technology served the practical purpose of helping Busa find his way through a massive corpus of Latin words, sorting, sifting, and organizing his database just as it did support the Nazis locate and persecute targeted groups of people: Jews, Roma peoples, LGBT peoples, BIPOC, people with disabilities, labour unionists, anarchists, communists, and artists. Both 
the priest and the Nazi empire were seduced by the same temptress, namely IBM and its modern market-ideology and "the practicality that confers the maximum priority to results, and forgets about the means used to reach those results" (Portillo and Costa 481). In other words, IBM offered its clients an innovative business solution for their own big data problems.

IBM's prowess as I have noted before is not in providing their clients with the most technically elegant solutions but rather offering their client a market-ready solution from their existing stable of technology solutions and communicating to the client that the technology which is being marketed to them is the one best suited for them. The IBM technology will be the one to ameliorate all the clients' predicaments. By this logic, it was not Busa that used the IBM punch-card technology on his lexical text analysis project, but rather it was IBM that was looking to enter the textual analytics market. IBM found in Busa, a client who would be an evangelist for their punch card technology solutions to others in his field of work. IBM was trading on Busa's ecclesiastic credentials to purge the punch-card technology of its Nazi legacies. The punch-card system that IBM had sold to Busa was a tried, tested, and true technology solution that had already gone through its product development stages. Popper and Buskirk breakdown the evolution of a technology through a marketplace or technology lifecycle (TLC) into six basic phases: "cutting edge, state of the art, advanced, mainstream, mature, decline" (24). At the time when Busa's project was being initiated, the punch-card was a mainstream product. I would speculate that IBM was trying to generate positive press coverage for its punch card technology through Busa and his humanities computing project. The media exposure that IBM would receive for Busa's project would connect punch-cards with the priest in the collective cultural memory.

The Index Thomisticus was at once both Busa's research project and IBM public relations project. IBM provided Busa with an off-the-shelf technology for which they did not have to incur any additional new research and development costs. The various computing technologies that went into the punch-card machine had been previously developed and well-established in the marketplace. IBM's predecessor, Herman Hollerith's Tabulating Machine Company, had developed a system for compiling census statistics in the 1880s. The general statistics technology was established in 1894 and been stabilized by 1907, leading to the creation of adding machines. Book-keeping technologies were developed in 1906. These calculating machines could add, subtract, multiply, and divide and had a market lifespan of 30 years or so. The punch card technology was developed in 1933 and stabilized by 1936 when the 80 column IBM cards were in production. Punch cards had a market lifespan of 30 years or so. The history of information systems based on punched cards is made possible firstly by the transnational memory network of patent laws and regulations that allowed one generation of product innovations to build upon the other (Heide 125) and secondly by the material supplies necessary for the production of punch cards. IBM had a stranglehold on the bill of materials needed to produce the standardized product, including a high-quality paper that was not readily available during the World Wars. To comprehend the political economy of punch-cards is to understand the reification of power. This data 
processing technology was capturing, circulating, and storing data that was, in turn, becoming the raw material to feed the racial surveillance apparatus of the Third Reich. Aly and Heim illustrate how the connections between "the politics of modernization and the politics of annihilation" can best be understood by focusing on how young, career-minded technocrats and academics were able to execute their plans because they were able to have their ideas sanctioned by those in the upper echelons of the National Socialist state hierarchy (1). The open and porous information flows between the Nazi state and the technocratic apparatus enabled Gustav Tauschek's, and by extension, Roberto Busa's research to flourish.

I felt it becoming evident reading Busa's account of how he used the IBM Punch Card machines to sequence, collate, and correlate data from the Index Thomisticus that Busa was truly a technocrat at heart and a religious specialist only by vocational training. Vanhoutte writes, "[ $t]$ he story goes that Busa met Ellison around 1954, congratulated him on his computing work, and went back to IBM to transfer the punch cards onto magnetic tape and use computer technology and programming for the publication of his Dead Sea Scrolls project in 1957" (127-8). When Busa mentions learning about how Rev. John W. Ellison used Remington magnetic tapes to prepare a concordance of the Bible, he was jealous of the headway Ellison was making and demanded that IBM give him access to more advanced hardware resources so that he too could make more progress on his project (Busa 85). Gluttony, greed, lust, pride, sloth, envy, and wrath are the cardinal sins in Christian teaching. Busa's revelation of being envious of the progress that Ellison has made in his project shows how lacklustre his commitment to the cardinal and theological values were. This behaviour is antithetical to the Jesuit tradition, customs, and practices. Jesuit priests are a religious community that has taken vows of poverty, chastity, and obedience, living in the community, sharing everything. The Jesuit order is known for its liberation theology, a social justice-oriented Christian theology that emphasizes a concern for the liberation of the oppressed and marginalized. Busa was working with technology that was drenched in the blood of the oppressed. Yet, he does not insert his Jesuit social justice commitment to his work. Busa's pedestrian concerns over the velocity with which the project could be completed suggest how he had become subsumed by the political economy of speed. Busa had been exnominated by the essences of capitalism, the never-ending blitzkrieg of the circulation of capital, technology, and speed. In this account, Busa's technological rationality becomes evident; he was seduced by the efficiencies afforded by the technological innovations establishing how thoroughly he had been interpellated into IBM's logic of militarized technoscience.

Probing the cultural memories that haunt the origin story of digital humanities, it becomes evident that the scholarly discourse exhibits an indifference for the humanistic and social concerns of the twenty-first century, namely, big data, biometrics, techno-politics, surveillance systems, etc. Carroll Pursell writes, "[a]s many of the founding generation [of American invention] feared, a technology not subordinated to our highest political aspirations has become a bulwark of our worst" (xiii). As a 
humanistic discipline, digital humanities scholarship must begin to excavate the problematic histories of the field and engage with the lineage of these data collection and data processing methodologies. The abject memories and grotesque legacies of IBM's punch cards can be traced back to Fr. Roberto Busa's humanities computing project. The traditions and practices of computer-assisted text analysis projects are strife with direct links to how the technology was used to "reduce flesh to pure information" (Browne 26). To surmise, I believe that by acknowledging the punch-card technology as an essential part of the genesis of digital humanities, scholars must have the moral courage to recognize that the field is complicit in the birth of surveillance capitalism, military contracting, and the technological apparatus of the security state.

\section{Works Cited}

Aly, Götz and Susanne Heim. Architects of Annihilation: Auschwitz and the Logic of Destruction, Princeton University Press, 2003.

Bauman, Zygmunt. Modernity and the Holocaust. Cornell University Press, 1994.

Birnbaum, David J., et al. “The Digital Middle Ages: An Introduction.” Speculum, University of Chicago PressChicago, IL, Oct. 2017, doi:10.1086/694236, accessed May 1, 2020.

Black, Edwin. IBM and the Holocaust: The Strategic Alliance Between Nazi Germany and America's Most Powerful Corporation. Dialog Press, 2012.

Bonfanti, Corrado. “Roberto Busa (1913-2011), Pioneer of Computers for the Humanities." Reflections on the History of Computing. IFIP Advances in Information and Communication Technology, edited by Arthur Tatnall, Springer, 2012, pp. 57-61.

Browne, Simone. Dark Matters: On the Surveillance of Blackness. Duke University Press, 2015.

Burton, D. M. "Automated Concordances and Word Indexes: The Fifties." Computers and the Humanities, vol. 15, no. 1, Springer, 1981, pp. 1-14, http://www.jstor.org/stable/30207364, accessed May 1, 2020.

Busa SJ, Roberto. "The Annals of Humanities Computing: The Index Thomisticus." Computers and the Humanities, vol. 14, no. 2, Springer, 1980, pp. 83-90, http://www.jstor.org/stable/30207304, accessed May 1, 2020.

Heide, Lars. Punched-Card Systems and the Early Information Explosion, 1880-1945. JHU Press, 2009. 
Hockey, Susan. "The History of Humanities Computing." A Companion to Digital Humanities, edited by Susan Schreibman, Ray Siemens, and John Unsworth. Blackwell Publishing Ltd, 2004. pp. 3-19.

Jones, Steven E. Roberto Busa, S.J., and the Emergence of Humanities Computing: The Priest and the Punched Cards. Routledge, 2016.

Jones, Walter. D. "Watson and Me: A Life at IBM." IEEE Annals of the History of Computing, vol. 25, no. 3, IEEE, July 2003, pp. 4-18, doi:10.1109/MAHC.2003.1226652, accessed May 1, 2020.

Kistermann, F. W. "Locating the Victims: The Nonrole of Punched Card Technology and Census Work." IEEE Annals of the History of Computing, vol. 19, no. 2, Apr. 1997, pp. 31-45, doi:10.1109/85.586070, accessed May 1, 2020.

Kistermann, F. W. “The Way to the First Automatic Sequence-Controlled Calculator: The 1935 DEHOMAG D 11 Tabulator." IEEE Annals of the History of Computing, vol. 17, no. 2, 1995, pp. 33-49, doi:10.1109/85.380270, accessed May 1, 2020.

Luebke, D. M., and S. Milton. "Locating the Victim: An Overview of Census-Taking, Tabulation Technology and Persecution in Nazi Germany." IEEE Annals of the History of Computing, vol. 16, no. 3 , 1994, pp. 25-39, doi:10.1109/MAHC.1994.298418, accessed May 1, 2020.

Maney, Kevin. The Maverick and His Machine: Thomas Watson, Sr., and the Making of IBM. J. Wiley \& Sons, 2003.

Metropolis, Nicholas, et al. A History of Computing in the Twentieth Century: A Collection of Essays. Academic Press, 1980.

Nyhan, Julianne, and Marco Passarotti. One Origin of Digital Humanities: Fr Roberto Busa in His Own Words. Springer International Publishing, 2019.

Passarotti, Marco. “One Hundred Years Ago. In Memory of Father Roberto Busa SJ." The Third Workshop on Annotation of Corpora for Research in the Humanities (ACRH-3), edited by Francesco Mambrini et al., Bulgarian Academy of Sciences, 2013, pp. 15-25.

Pauwels, Jacques R. “Profits “Über Alles!" American Corporations and Hitler.” Labour / Le Travail, vol. 51, 2003, pp. 223-249. JSTOR, www.jstor.org/stable/25149339, accessed May 9, 2020.

Popper, Edward T., and Bruce D. Buskirk. “Technology Life Cycles in Industrial Markets.” Industrial Marketing Management, vol. 21, no. 1, Feb. 1992, pp. 23-31, doi:10.1016/0019-8501(92)90030-W, accessed May 9, 2020. 
Portillo, E., and P. Costa. “The Role of Technological Acceleration in the Crisis of Modernity: A View by Paul Virilio." 2010 IEEE International Symposium on Technology and Society, 2010, pp. 480-83, doi:10.1109/ISTAS.2010.5514603, accessed May 9, 2020.

Pugh, Emerson W. Building IBM: Shaping an Industry and Its Technology. MIT Press, 1995.

Pursell, Carroll. The Machine in America: A Social History of Technology. JHU Press, 2007.

Randell, Brian. The Origins of Digital Computers. Edited by Brian Randell, vol. 1, Springer Berlin Heidelberg, 1982.

Ricœur, Paul. Freud and Philosophy: An Essay on Interpretation. Yale University Press, 1970.

Ricœur, Paul. Memory, History, Forgetting. University of Chicago Press, 2004.

Rockwell, Geoffrey. “The Index Thomisticus as Project.” Theoreti.ca, 14 Mar. 2016, http://theoreti.ca/? $\mathrm{p}=6096$. Accessed May 1, 2020.

Reichert, Ramon. "Big Humanities Project." Encyclopedia of Big Data, edited by Laurie A. Schintler and Connie L. McNeely, Springer International Publishing, 2017, pp. 1-5, doi:10.1007/978-3-319-32001-4_221, accessed May 1, 2020.

Sprokel, Nico. “The 'Index Thomisticus.” Gregorianum, vol. 59, no. 4, GBPress- Gregorian Biblical Press, 1978, pp. 739-50, JSTOR, http://www.jstor.org/stable/23576117, accessed May 1, 2020.

Stebenne, David L. “Thomas J. Watson and the Business-Government Relationship, 1933-1956." Enterprise \& Society, vol. 6, no. 1, Cambridge University Press, Mar. 2005, pp. 45-75, doi:10.1017/S1467222700014294, accessed May 1, 2020.

Terras, Melissa. “For Ada Lovelace Day-Father Busa's Female Punch Card Operatives” Melissa Terras' Blog, 15 October 2013, http://melissaterras.blogspot.be/2013/10/for-ada-lovelace-day-fatherbusas.html, accessed May 8, 2020.

Terras, Melissa and Julianne Nyhan. “Father Busa's Female Punch Card Operatives.” Debates in the Digital Humanities 2016, edited by Matthew K. Gold and Lauren F. Klein. University of Minnesota Press, 2016, https://dhdebates.gc.cuny.edu/read/untitled/section/1e57217b-f262-4f25-806b4fcf1548beb5, accessed May 8, 2020.

Vanhoutte, Edward. "The Gates of Hell: History and Definition of Digital | Humanities | Computing." Defining Digital Humanities: A Reader, edited by Melissa Terras, Julianne Nyhan and Edward Vanhoutte, Routledge, 2013, pp. 119-156. 
Winter, Thomas Nelson, "Roberto Busa, S.J., and the Invention of the Machine-Generated Concordance" (1999). Faculty Publications, Classics and Religious Studies Department. 70.

https://digitalcommons.unl.edu/classicsfacpub/70/, accessed May 1, 2020. 